\title{
RE-THINKING SOCIAL THEORY IN CONTEMPORARY SOCIAL MOVEMENTS
}

\author{
NADIA FERRER \\ SCHOOL OF SOCIAL AND INTERNATIONAL STUdIES, UNIVERSITY OF BRADFORD
}

\begin{abstract}
In current and future situations of trans-global crises, social dissent and related practices of resistance cut across conventional country boundaries. Expressions of dissent and resistance pursue change through unconventional practices not only to challenge current governance, but to re-invent participation. They seek to impact society by transforming acquired values, subjectivities and knowledge. Despite these transformations of people's subjectivities, majoritarian theories examining social movements still focus on finding rational patterns that can be instrumentalized in data sets and produce generalizable theoretical outcomes. This paper problematizes how social theory makes sense of collective action practices on the ground. Everyday non-discursive practices prove productivity-led theories' increasing disengagement with their object while challenging the excessive bureaucratization of scientific knowledge (Lyotard, 1997). That is, people experiment collectively with their capacities, and create their own initiatives and identities which do not follow determined patterns but do-while-thinking. The dichotomist approach of majoritarian debates in collective action theory is critically analysed by introducing the work of 'minor authors' and 'radical theorists'. The fundamental purpose of this paper is to open a discussion space between the field of social action theories and activism knowledge, hence encouraging the creation of plateaus that blur academic boundaries and construct new subjectivities beyond "the indignity of speaking for others" (Deleuze in Foucault et al., 1977. p. 209). Drawing on the experience of the 15th of May 2011 in Spain, I analyse how radical theory reflects on current movements and collectives.
\end{abstract}

\section{Keywords}

radical theory, collective action, social movements, Indignados

Corresponding author:

Nadia Ferrer, Email: N.Ferrer@student.bradford.ac.uk 
"(...) we are trying to reinvent and experiment as the best and more legitimate way to truly own our destiny, without the money dictatorship or the patronization of the politicians. (...) The streets and the squares create a new language in order to express desire and collective emancipatory power" Abrasad@s de Sol in ¡Indignados! 15M (2011, p. 25)

S ometime ago I did a presentation where I spoke about the 2011 mobilizations in Spain. I described the background of the 15th of May encampments, focusing on the ways citizens without previous mobilization experience constructed and engaged with participatory decision making processes. A question formulated during the discussion time has remained with me since. One of the attendees compared 15-M movement with May 68. In his opinion, both movements led to the same problem of much ado about nothing. How could I say that this was not going to happen with the mobilizations in Spain? Perhaps - he presumed - I should have talked from an International Relations perspective, and name patterns, policies and quantitative outcomes. And he was probably right; I did not have an answer for his question with the exception that this was far from the pretensions of my analysis. I espoused an argument about peoples' politics and participatory relations. Attempting to establish patterns and predictions within causality and rationalist theories would have automatically refuted my argument. I was talking about people's acknowledgement of power (pouvoir) to experiment collectively with their capacities and construct their own initiatives and identities beyond rationalist analyses.

The question I was asked somehow summarizes the current problematic of social theory. On the one hand, it has become obvious how contemporary movements - especially after the 2010 protest such as the Arab Spring, the 15-M movement in Spain, the occupy movement, etc. - have widened and accentuated the legitimation crisis of representative democracy within the capitalist system. Following Foucault's idea of positive resistance, these increasing de-socialization processes in which the state has embarked have opened opportunities for social mobilization and transformation. On the other hand, mainstream approaches to social phenomena insist on developing rational-thinking theories at the cost of neglecting minor perspectives, which walk hand in hand with the complexity and multiplicity of current movements.

I claim that current discourses are too static and lack in the necessary plasticity that characterises current social movements. People's participation in recent protests has rather an experimental and nomadic character, encouraged by desires and possibilities opened by the 'unknown', with the certainty that any change will come from within peoples' struggles. Dismissing what Foucault called "disqualified knowledge" (Foucault, 2001), as the remark made during the presentation mentioned above implicitly suggests, misses what the motor of these movements is, their metamorphoses of power or, as Deleuze puts it, "becoming minor" process. Social movements are composed by people's experiences. They build political and cultural relationships, and recover discussion and participation spaces which overcome present democratic practices, whether these are formally recognised by those of us doing social theory or not.

In keeping with these ideas, I explore how a 'revolt' is not only a failed attempt to change the world by the means of 'total revolution' but also a composition of experiences that constitute the world, open spaces, create and transform subjectivities. In doing so, firstly I review some approaches to the study of social phenomena. Secondly, I present what in my opinion is the most problematic feature of social action approaches. That is, the excess of objectivization and 
categorization in the search for operational patterns which dismiss participants' knowledge and practices. The third section of this article analyses collective action in relation to opening moments/events/situations of action that cross-out the social. Collective action is seen here not as a mere reaction but as a creative continuity seeking to highlight the cracks at the edges of the capitalist system (Holloway, 2010), and to inaugurate passages within the collective thinking. In the case of protest movements in Spain, for example, I will argue that beyond the claims of 15$\mathrm{M}{ }^{1}$ events, this movement embodied to a certain extent a legitimating shift within the society.

I focus specifically on the participation dynamics and discourses drawn from two platform organisations born between 2008 and 2011, namely PAH (Plataforma de Afectados por la Hipoteca) and Iaioflautas (senior citizens' platform whose actions/performances are directed against diverse objectives). I undertake this analysis by looking at current social theories and militant researchers whose analysis tries to humanize social theory (Chesters, 2012) and conceptualizes collective participation beyond the structural and rationalist debates, discovering "new possibilities with the present, turning bottlenecks and seeming dead ends into new opportunities of joyful insurgency" (Shukaitis \& Graeber, 2007, p. 12). Following Deleuze and Guattari (2004), I call for the deterritorialization of majoritarian social action analyses if it wants to understand the transformational dynamics of today's movements, which "modes of existence" go beyond the margins of rational objectification (Day, 2005, p. 175).

\section{Dualist Debates in Social Theory and Beyond: Re-claiming Spaces}

This section aims to critically examine the characteristics of mainstream approaches to the study of social phenomena and social movements. As mentioned in the introduction of this article, I argue that social theory is still strongly rooted in dualist debates despite recent attempts to promote a more inclusive framework. Thus, looking at the current protest movements arising since the 2010, including the 'Arab Spring' mobilizations, the encampments in Spain, the Occupy Movement, Wisconsin Wave, etc., one may be tempted to search for explanations within the 'old' social movement paradigm. Indeed, the idiosyncrasy of the political and social situation of some of these countries, together with the context of global crises, makes the search for behavioural and structural patterns very appealing.

Olson's (1965) rational choice theory (RCT) posits that individuals' mobilization is the result of utility maximization; mobilization is reduced to a goal-oriented behaviour determined by certain constraints. In contrast, collective behaviour authors, such as Gurr (1970), Smelser (1963) and Turner and Killian (1972) individuated in grievances, ideology and discontent are the reasons for protest behaviour (Opp, 2009, p. 127; Chesters \& Welsh, 2011). Talcott Parson's (1961) Structural Functionalism Theory reinforced this approach and together with Smelser's theory of Collective Behaviour focussed on the structural conditions, such as political, economic and societal factors as determinants of the appearance of a social movement (Chesters and Welsh, 2011, p. 6).

These approaches influenced the resource mobilization model, the principles of which are still widely applied by many authors. Resource Mobilization Theories (RMT) was first formalized by McCarthy and Zald in an influential paper titled "Resource Mobilization and Social Movements: A Partial Theory" (1977). These authors stated that a social movement

\footnotetext{
1 I will be referring at the protest in Spain during the 15th May 2011 as 15-M movement. I will also refer to them as the indignados as I consider this is the name received by the mainstream media seeking to relate this movement to Stephan Hessel's book, “indignez-vous!” (2010). I consider that this concept is a metonym which does not represent the totality of the movement.
} 
is "a set of opinions and beliefs in a population which represent preferences for changing some elements of social structure and/ or reward distribution of a society" (McCarthy \& Zald 1977, p. 1217-1218). A "social movement organization" refers then to that group capable of identifying its goals within the preferences of the movement and implements these interests consequently (ibid).

The above definition presumed to explain the emergence of collective action based on a rational-choice framework as well as the capacity for individuals within social movements to act as entrepreneurs capable of making cost/benefit analysis of their choices. In his social psychological expansions of RMT, Klandermans partially acknowledges these critics to RTM, while taking into account the socio-psychological reasons for an individual to participate in an action that might not be collective yet (Klandermans, 1984, p. 585). Moreover, McCarthy and Zald recognized in a later work that their theory is constrained by the acceptance of scope conditions which are supposed to be characteristic of a free society, such as voluntarism, freedom of speech and press, etc. (cf. Opp, 2009, p. 128). But to determine and categorize what scope conditions are and how they are combined in order to reach an outcome (as well as what fits into their definition) goes back exactly to the root of the problem. That is, excessive operationalization and categorization of social movement analyse.

Nevertheless, whether Social Movements are analysed from micro perspectives (by looking at agency), or from macro perspectives (by examining structural constraints), and in spite of RMT's explicit efforts to change this view, Social Movements are still implicitly assumed to be something breaking the normality, a deviance from society (Chesters \& Welsh, 2011, p. 6). Even if there is a considerable effort from approaches such as Oberschall's (1973) breakdown theory, Tilly's solidarity model or, from authors such as Tarrow (1998) to go beyond Olson's rationality and to examine other macro and cultural elements, current movements' diversity tends to elude classical sociological analysis in many cases.

The aim of these theories - mainly developed in the United States - continues to be providing a totalizing explanation by looking at foundational grounds of social movement. In some of these theories there is an implicit assumption of a free society, which ignores the underlying powers and discourses conditioning social structures. Even though collective actors act rationally at some stage, this rationality cannot be generalized and categorized in a single theoretical approach that pretends to represent finite subjects. Rationalist-based approaches presume the continuity of rational-thought as if these discursive processes would derive independently from nondiscursive practices. However, thinking and reflecting subjects are not necessarily related to the "rationality" assumptions of instrumentalist-led theories. Neither are they necessarily related to tactical thinking, success, leadership or reward aspirations which characterize these analyses.

In the European context, the analysis of social movements was led by a structure/motivation position grounded in classical Marxist traditions (cf. Althusser, 1997). From the 1960s, by drawing on European social theory and philosophical traditions, social theorists attempted to explain collective action from a post-industrial and post-materialistic perspective. This approach was anticipated by Roland Inglehart as he argued that once society's basic needs have been satisfied and "have attended a certain level of prosperity" (1971, p. 995) priorities and values change giving birth to a new type of social claims.

Other authors, such as Melucci (1989, 1996), Habermas (1976, 1985), and Offe (1985), introduced the notion of New Social Movements (NSM) to the study of social movements. NSM theorists argue that social movements, especially after the 1968, are characterized by 'new' strains and grievances typical of post-industrial societies. The NSM approach is not homogenous and there exist different variants, which give different weight to political and cultural elements (Buechler, 1995). For instance, Buechler differentiates between those authors that emphasise 
culture, such as Habermas or Melucci, and those for whom political structures have a major influence, such as Castells or Touraine (ibid). Taken together, however, NSM perspectives attempt to explain 'why' individuals who do not come from a labour or peasant mobilization tradition and do not belong to marginalized sectors of society, decide to mobilize. In contrast to the more instrumentalist approaches briefly mentioned at the beginning of this section, NSM theorists focus more strongly on the analysis of frames, and on the construction of symbols and identities related to collective actions. Ultimately, while instrumentalist theories focus on 'how' social movements emerge, NSM theories emphasize 'why' social movements emerge.

Nonetheless, NSM approaches still examine social movements from an objective and neutral perspective. Social Movements are still observed from the outside, in order to find operational patterns that provide the world with a unitary theory. The complexity and multiplicity of subjectivities are compressed into general categories and variables imposed from an external and "neutral" point of view. NSM approaches ignore any form of knowledge coming from within the movements that breaks with the linearity of these patterns.

\section{Agency and Structuralist Debates}

As it is possible to note from this brief theoretical outline, the analysis of social movements seems to revolve around a series of dualist explanations, namely old vs. new social movement paradigms, micro and macro levels, agency and structure, North American vs. European schools, political vs. cultural approaches, rationalism and irrationalism, etc. Most of the debate among social theorists tends to be framed within agency and structuralist views. While utilitarian models presume that political and economic reality is affected by structural variables, models based on the analysis of the cultural contexts, question the type of society and its immobility (Martínez et al., 2012, p. 13).

Several authors have sought to put an end to this dualist debates between agency and structure. For instance, Habermas' critical theory conceptualizes social action as the result of a disagreement between social structures and the democratic State. His structural theory of Communicative Actions centres on aspects of agency, albeit it relies on the capacity of individuals to intervene critically in their own socio-historical reality (Saidi, 1987, p. 252- 254). His critics reproach him for assuming the capacity of individuals to communicate, act and choose rationally without entering in conflict as well as for overlooking the complexity of the social phenomena (ibid, p. 260; Buechler, 1995, p. 446). Others, such as Rorty, accuse Habermas of idealising reason and hope for enlightenment as opposed to imagination and 'aesthetics' (see Shusterman in Rorty, 2001, p. 135; Seidman \& Alexander, 2001, p. 4). According to this view, Habermas' approach cannot explain agency beyond rationalist explanations. Similarly to RMT, Habermas' approach explains social action on the basis of the capacity of individuals to rationally identify, to set strategies and engage in achieving their goals.

Identity theorists, such as Alberto Melucci, on the other hand, try to fill the gap between structuralist and agency approaches and the process that brings peoples together by focusing on how actors construct their "meanings, communicate, negotiate, and make decisions" (Melucci, 1996, p. 331). As Melucci puts it, "how certain individuals come to recognize themselves in a more or less shared sense of 'we”" (Melucci, 1989, p. 20). By doing so, Melucci moves beyond the dualism of the structuralist analyses and RMT to more epistemological approaches by explaining how collective action is constructed. The link between the previous approaches and the construction of collective action is maintained through the concept of identity. Identity is seen by Melucci as "an interactive and shared definition produced by several interacting individuals who are concerned with the orientation of their action as well as the field of opportunities and 
constraints in which their action takes place" (ibid, p. 34). In particular, Melucci examines three dimensions of collective action. First, mutual recognition of the actors; second, the existence of a conflict or consensus; and last a will to transgress the limits or to adapt the "decision-making" structures (Ibid, p. 28).

However, criticisms of Melucci's approach, such as the ones coming from Opp (2009), and from Gamson (1992), point out the lack of clarity in the operationalization of the concept of collective identity. Interestingly, these criticisms show exactly what is the issue with social theory (see especially Opp, 2009), as they analyse his approach using a strongly rationalistic framework, and the concepts of efficiency, operationalization, and standard categories (or the lack these) as an argument. Firstly, these critics ignore the constructed character and the underlying powerrelated processes of the concept of identity; secondly, they presume that collective action is influenced only by one finite aspect of this identity; third, they accept cost-benefit motivation as a normalized measurement standard in the analysis of collective action; and last, the construction of this identity is presumed to be acknowledged a priori. That is, they assume not only the actor's capability of recognizing these relations of the 'we' but also to exist as such before the action.

Other attempts to go beyond the agency-structure dualism may be found in the work of Giddens and Bhaskar. Giddens tries to overcome the structure-agency dualism, by suggesting a model that combines subjectivism and objectivist theories (Giddens, 1984, p. xx). In his structuration theory, Giddens argues in favour of the importance of recognizing the dialectical relation between structure and action (agency). Similarly, adopting a critical realism approach, Roy Bhaskar $(1989,1998)$ attempts to overcome this dualism through the idea of transcendental realism. Bhaskar's ontological perspective tries to reconcile realism with anti-foundational criticisms. The real is then "stratified" and divided between reality itself, the actual, and the empirical world. According to this view, the empirical world mediates between supposed objective reality and the world of our perceptions, the actual. The empirical, which refers to the characteristic observed in a determined event, is assumed to contain both possibilities. That is, what "can be" and what "will be," although Bhaskar does not pretend to exhaust or predetermine what "could" or "has happened" (Collier, 1994; Sayer, 2010). Bahskar is concerned with uncovering the power structures that affect social behaviour; however, he understands power as 'capacity' or potential of what 'ought' to be (Collier, 1994, p. 26). Thus, he aims to emancipate the 'object' from its falsity and exclude from the analysis anything that is not consciously organised.

Even if Giddens and Bhaskar manage to escape the agency $\backslash$ structure dualism, they centre their conceptualizations on the discussion of the object-subject relationship. Graeme Chesters argues that while these are seen as promising ontologies, which presuppose a relational understanding between society and individual, the link between their epistemology and their methodological explanations remains underdeveloped (Chesters, 2012, p. 4).

Ultimately, looking at the theories mentioned up to this point, some general criticisms may be formulated. In general, there is still a strong tendency to analyse social movements from a Resource Mobilization perspective by focusing on economic, rational and utilitarian explanations and operational outcomes. This issue has been pointed out by several authors. Burawoy, for example, differentiates between instrumental knowledge, which is founded on policy and professional sociology, and public and critical sociology, founded on reflexive knowledge (Burawoy in Scholl, 2012, p. 13). Donatella della Porta, on the one hand, recognizes "what is actually happening 'on the ground' [of social movements practises] is rarely studied" (2013, p. 2). On the other hand, Ross accuses rationalist choices as seeing themselves as the "tribunal" to decide and judge what is real (Ross, 2002, p. 4). Non-economical/rational choices are excluded from these decisions. Hence, majoritarian theories fail to provide real accountability 
of the "event" (ibid).

Likewise, Steven Seidman, points out that sociological theory "has lost most of its social and intellectual importance" due its increasing disengagement with conflict and debates taking place in the current public sphere. Thus, theory "has turned inwards and is largely self-referential" (Seidman, 1997, p. 43). For this author, sociological theory needs to abandon the idea of discovering a totalizing rational-model that explains society, in favour of a "social theory" that "opens present and future possibilities, detecting fluidity and porousness in forms of life where hegemonic discourses posit closure and frozen, natural social order” (ibid, 1997, p. 44).

In keeping with the criticisms illustrated here, I argue that there is a need for a shift in social theory studies that opens the debate to the knowledge-praxis that has been left unexplored. Current social movements escape the stratifications and categorizations required by classic 'scientific' academic knowledge. There is thus the necessity to break with these discourses in order to encounter different theoretical possibilities that would enable the explanation of the transformative processes of current social movements. The next section explores the work of authors that acknowledge this emancipatory necessity and argue in favour of an epistemological shift along these lines.

\section{The Unsocial of the Social Theory}

Building on Seidman's and Della Porta's criticisms mentioned above, the rest of this article will elaborate on the approaches claiming to abandon the underlying presumption of the finite and unity of collective subjects, in favour of the multiplicity that social movements show on the ground. Many critics have pointed out that there is an increasing disengagement of sociological theory from its object of study. Post-structuralist approaches such as those from Lyotard (1997), Foucault and Deleuze (in Foucault et al., 1997), post-modernism authors (Seidman 1997, 2001; Baudrillard 2000, 1983) as well as feminist theorists (Butler 1990; Braidotti 2012; Irigaray 2002) point out not only the self-referential and instrumental character of sociological theory, but also its stubborn pursuit of an ideal of normative regulation of knowledge in which difference and ambiguity have no place.

Luce Irigaray, in her work To Speak is Never Neutral (2002) dedicated a chapter to the scientific language ("Is the subject of Science Sexed?"). She asks the reader and herself what is the responsibility of the academic and institutional discourse in relation to the constitution of the subject and, more specifically, of gender. Foucault makes a similar remark, referring to the intellectuals as "agents" of the system of power, "the idea of their responsibility for "consciousness" and discourse forms part of the system" (Foucault et al., 1977, p. 207). Intellectuals are no longer representative of people's subjectivities. Individuals are capable of representing themselves in spite of the existence of "a system of power which blocks, prohibits, and invalidates this discourse and this knowledge" (ibid).

The dynamism of the transformative and reflexive knowledge of the social still requires analysis within the steadiness of majoritarian theories. The role of the intellectual is then to fight against the "forms of power" that convert him/her in part of this game (ibid). In order to do so it is necessary to creatively re-take power by re-claiming spaces and open social theory to the risk of having this discussion. This is precisely the object of this paper. Accordingly, I turn now to the work of authors such as Foucault, Deleuze and Guattari and feminist theory, and the work of those referred to as "minor authors" (Deleuze et al. 1983) whose approaches escape the structure/ agency dichotomy (Fox 1998, p. 415) of previous theories. I attempt to unthink social science (Scholl, 2012; Holloway, 2002) by analysing theories on the 'margins' as situated on a multiplicity 
of experiences. In this sense, I borrow from Foucault's notion of ontology the idea that power/ knowledge is not only constituted by rules of discursive formations as something repressive, but also by "non-discursive practices," which are, on the contrary, productive processes that enable the creation of human capacity (Fox, 1998, p. 416; Butler, 1990, p. 139). Foucault breaks with structuralist ideas by thinking of power beyond its coercive expression and, with agency-centered approaches that "de-centre the individual" (Fox 1998, p. 41. 7). Power/knowledge is then the link that puts in relation discourses and non-discursive practices (ibid). Similarly, drawing from Simone de Beauvoir's work, feminist materialism (beyond the Anglo-American deconstructionist approaches from Butler and Scott (1992)) has overcome these dualisms by producing creative alternatives of a sexually "embodied and embedded kind" which Braidotti names "figurations". These are "ways of expressing different subject positions" that "renders the non-unitary image of a multi-layered subject" (Braidotti, 2012, p. 13-15). The problem is then how to represent this non-linear fluidity "in-between flows of data, experience and, information" since in our thinking processes the idea of objectivity and linearity still prevails (ibid).

Deleuze and Guattari's work expand on this point by seeing the social as an "abstract machine" which "draws lines of continuous variation" (Deleuze \& Guattari, 2004, p. 110). This machine refers to the dynamics through which transformations are produced. They name these lines of change and creation "lines of flight". The "abstract machine" is then singular and does not contain the signs, interpretations and subjectivities to which stratification is human being bound (ibid, 2004, p. 148). However, it is necessarily bound to the "diagram of assemblages" which is collective and concrete, "treats variables and organizes their highly diverse relations as a function of those lines" (ibid, 2004, p. 111).

The assemblages are related to the level of deterritorialization, and determine which lines will form part of a set of rules or which will be part of the "fluid matter" (ibid). Social action should work from the inside to the outside, aiming to 'become' fluid matter, to metamorphose and to bring lines of flight to the margins of the plane of consistency by undoing the territorial strata. Experimentation then becomes a synonym of movement, occupying spaces, inventing lines of flight and passages fuelled by the desire and passion of ontological becoming. It is in this sense that movement is necessarily rhizomatic ${ }^{2}$, it has no beginning or end, is horizontal, multiple and non-hierarchical in opposition to the vertical relations of arborescent forms. This implies stripping the subject "of its old genderized, racialized, normalized straitjacket and relocated into patterns of different becomings" (Braidotti, 2012, p. 21).

However, the process of 'becoming' occurs from the interior to the exterior through infinite sequences of deterritorialization and reterritorialization, that is through conflictual processes between rhizomatic and arboreal (hierarchical) constructions. Accordingly, an action is rarely completely rhizomatic. It is the fluid matter mentioned before, that which escapes the arborescent stratification in order to move to the next sequence. The Body Without Organs (BWO) which represents the "absolute" deterritorialization, is constituted by infinite matter, is the result of a rhizomatic transformation, and hence, a multiplicity (Deleuze \& Guattari, 2004, p. 148) in itself. These authors argue in favour of the nomadic behaviour of positive deterritorialization of the subject, which can only be achieved by becoming 'minor', pushing resistance and tensors to the margins.

Deleuze and Guattari's concepts of 'nomadic' and 'becoming' are referential for those authors who put movement at the centre of their thinking, such as Rosi Braidotti. For Braidotti (2012, p. 3), nomadic theory refers simultaneously to a "monistic vision of matter" and to the "no

2 Deleuze and Guattari borrow the concept of rhizomatic from biology language. It refers to the characteristics the roots of some plants possess. For example, if separated into pieces any of the parts will give rise to a new plant. 
unitary vision of the subject" which is defined by its motion. Monistic matter is here understood as the embodiment of mind beyond Cartesian dualism. Thought is not only composed by organic, human and rational consciousness (ibid) but by non-rational and inorganic elements whose relation is nomadic and transformative.

Contradicting this view, Badiou (2000) simplifies Deleuze's multiplicity to a Spinozist' theory of being(s), the One (true substance) in opposition to the many (multiple) (Roffe, 2012). However Badiou's criticism is based on axiomatic interpretations of Deleuze's multiplicity. While Badiou bases the concept of multiplicity on axiomatic sets dismissing the role of problematic (events), Deleuze defends the co-dependency of both. To adjust to the rigor of axiomatic sets necessarily implies to select and exclude and thus eliminate events.

These different ontological perspectives are at the heart of the social theory discussion pretended in this paper, what Deleuze refers to as "royal" and "nomad" or "minor science" (Smith, 2003, p. 3-4). The 'royal' perspective has been dominant in the analysis of social movements, degrading and eliminating "minor" approaches. Nevertheless, the inclusion of the event in its own right is leading the analysis of current movements to different more plastic and inclusive approaches.

This epistemological shift of the theory is being recognized by several authors concerned with social phenomena. For example, from the Latin-American perspective, Martínez et al. (2012) argue that movements' practices on the ground overcome theoretical analyses. Movements engage in an emancipatory process and knowledge of reality of which the source is outside western academic influence (Martínez, et al. 2012, p. 18- 19).

Martinez et al. situate the origin of this epistemological shift around the '90s with the Zapatistas movements, the Piqueteros in Argentina, the Movement Sin Tierra (MST) or the indigenous and peasant movements in Bolivia. The difference, according to them, is due to the fact that these movements are "constructed at the margins of the modern world" through process of rupture and liberation from the western society (ibid). This process is not only limited to some specific fields but claims to have a multidimensional character that affects all the areas of the social and political life and therefore is seen as endless and in construction. Raúl Zibechi, to give a specific example, sees these theories underlying what he calls the 'Aymara revolution' (Zibechi, 2010, p. 7):

The Aymara experience is not only linked with the continental struggles but it also adds something substantial- the construction of actual non-state powers. By this, I am referring to powers that are not separated from or splintered off from society (...) in the Aymara world this capacity is distributed and dispersed through the social body and ultimately subject to assemblies in the countryside and the city.(...) The non-state powers of the Aymara were born in territories in which the community machine operates: social mechanisms that are de-territorialized and 'de-communalized' in order to be used by society in movement as non-state forms of mobilization and to create space where- far beyond mere rhetoric- the dictum 'to lead by obeying' functions.

I have briefly illustrated here some examples of how authors working from different angles have acknowledged the increasing disengagement of social theory from its object of study. These authors argue for an epistemological shift in the analyses of social movements. This shift is based on ontological perspectives closer to Foucault's and Deleuze's views on events and non-discursive practices as well as the multiplicity of the subject. In the next section, I explore further in which way these theories engage on the ground with contemporary movements and participatory dynamics 
in Spain. Specifically, I focus on the idea of deterritorialization, innovation and experimentation on social action. Similarly to other authors (Chesters 2012; Day, 2005; Graeber \& Shukaitis 2007; Martínez et al. 2012; Urry 2003), I argue that since the late 1990s social movements need to be analysed by looking at their differences and exceptions that resist categorization within social theory.

\section{The Becoming of New Protagonism}

To sense the dynamics of resistance and creations across the interlinked world space is to start taking part in the solidarities and modes of cooperation that have been emerging across the planet since the late 1990s Brian Holmes (in Graeber \& Shukaitis, 2007, p. 42)

"All of them must go" ("que se vayan todos") was one of the most chanted slogans on the 19th and 20th of December 2001 during the Argentinian crisis. Likewise, 10 years later in Spain during the demonstrations of the 15th of May 2011, people repeated similar slogans: "they do not represent us" ("no nos representan"). Although 12 years had passed, there are plenty of activist knowledge-practices and meanings that link the two events. See for example, the protest methods between the piqueteros movement in 2001 and the Asturian (Spain) miners in July 2012, or the escraches that the Plataforma de Afectados por la Hipoteca (PAH is a platform that gives support to people threatened with being evicted from their homes as they cannot pay their mortgages) engage in. Even though, there were elements of spontaneity in the last protest mobilizations in Spain and in December 2001 in Argentina, these protests did not appear from nowhere; there is an extensive and diverse background of mobilizations that were transformed by these two movements. For example, in Spain we could refer to the demonstrations against the Ley Orgánica de Universidades (L.O.U.) (Fundamental University Law) of 2001, the movements Nunca Mais (Never Again), born as a consequences of the oil spill of Prestige, a single-hulled oil tanker that sank in front of the Galicia coastline in November 2002, the campaign against the Iraq war in 2003; the demonstrations against the Partido Popular (Peoples Party) after the Madrid Bombings on 11th of March 2004, the movement against the Bologna Plan, and more recent movements in favor of a dignifying home, the Wikileaks phenomenon and the demonstration on March 2011 against the anti-piracy law known as Ley Sinde.

In this section I compare the 15-M events in Spain and the Argentinian crisis. I try to contextualize theoretically the vector relations that contain these events. That is, I attempt to de-construct the lines of transversal continuity that intervene in the production of subjectivities. This production of subjectivities is, according to Negri et al., the result of an accumulation and sedimentation of other subjectivities and events (Negri et al., 2008). Peoples' reaction to the Argentinian crisis in 2001 and the protest of $15-\mathrm{M}$ events taken as an example, represent two moments/situations that cut across the plane of consistency, lines of flight that go beyond the hierarchic elaboration of rational theories. To put it in Deleuze's and Guattari's words, I explore the multiplicity of rhizomatic assemblages that have deterritorialized and territorialized the Argentinian and Spanish social space multiple times.

Deleuze and Foucault, in their conversations about Intellectuals and Power, argue that "from the moment that a theory moves into its proper domain, it begins to encounter obstacles, walls, and blockages which require its relay by another type of discourse [...] No theory can develop without eventually encountering a wall, and practices are necessary for piercing this 
wall” (Foucault et al., 1977, p. 2006). In that sense, these two events, and particularly the 15-M to which I will be referring later, inaugurate the visualization of alternatives, experiences and knowledge-practices innovations motivated from within the society. Thus, I will refer to these practices on the ground which "pierces the wall".

Christian Scholl, in his work Two Sides of the Barricade (2012), analyses summit protests from a similar perspective, as "events that constitute possibilities" (2012, p. 6). He anchors his argument on Deleuze and Guattari's idea that events cannot be outdated as they are open (or openings) to the possible (ibid). I shall take the same approach here and see these events as initiators of social transformative processes. These shifts, on the one hand, have translated into a different type of action where the politics of demand gives way to politics of the act. It seems then that there is a non-verbalized agreement of some scholars on approaching the analyses of the recent social movements from a different perspective, beyond traditional mainstream views. Scholl, as other materialist theorists such as Braidotti (2012), conceptualizes these politics as a "product of doing" (p. 7). Following once again Deleuze's and Guattari's concepts, it can be said that one of the main features of this doing is their horizontal character ${ }^{3}$ (at least at some point of their process) through which the construct of rhizomatic relationships is formed (Deleuze \& Guattari, 2004). As it has been said before no movement is purely rhizomatic, but determined by spaces and time. However, the event is the "situation" of cut, where non-discursive practices flow through the pierced wall and escape rationality.

This is the moment of absolute deterritorialization. What is "contained" in this situation and its outcome cannot be fixed in a theory, as it is movement in itself. Therefore, in the same way that talking about the present-time is part of linguistic agreement; diagrams of assemblages reterritorialize and rationalize movements just to deterritorialize again within a new event. Collectivo Situaciones calls this new type of movement new protagonism. This is not a "new subject" as it does not reach such a consistency. Rather, it moves within multiplicity but is delimited by its situations (Collectivo Situaciones, 2002, p. 38). As I shall later illustrate with examples, the difference between this "new" tendency and NSM theory lies in this heterogeneity and rhizomatic behaviour as well as in the more inclusive nature of these movements. Martínez et al. (2012) find the key of this difference in the emancipatory character of these movements. The action does not come from the outside but from within the margins, it has no concrete form and yet it is transformative. Such fluidity goes beyond rational claims influenced by capitalist views of the world.

Recently, researchers have started to make use of the term 'rhizomatic' in order to refer to the form that social movements take. Thus, Chesters and Welsh (2006) use this notion to refer to the manner in which anti-globalization movements engage with action. Following these authors, Castells also refers to the 15-M as a "rhizomatic revolution" (Castells, 2012, p. 110155). Accordingly, these movements resist being branded and escape traditional strategies and tactical explanations at the same time that they reject acting through hegemonic forms of action (Day, 2005, p. 8-9). Richard Day argues "most interesting about contemporary radical activism is that some groups are breaking out of this trap by operating non-hegemonically rather than counter-hegemonically" (ibid). Hence, to understand these movements is to understand the ongoing shift of Gramscian hegemonic explanation by affinity forms. This means going beyond explanations for which the social struggle is conditioned by the concept of bourgeois hegemony underlying all spheres of the political and social life.

3 The fact that there is no recognisable leadership confused the media, especially during the events of $15-\mathrm{M}$ where "not even spokespersons were recognized" (Castells, 2012, p. 129). This was however not new; we need to go back to Seattle in 1999 to and remember how the media broadcast about what was happening in the streets. 
On the other hand, the slogans mentioned at the beginning of this section embody the increasing disagreement between the State and the supposed sovereignty powers where political legitimacy rests. State sovereignty has been transferred to the market flows, which forces us to rethink the Hobbesian state of nature (Colectivo Situaciones, 2002, p. 34). Argentinean economist, Marcelo Matellanes said, "It is the failure of a socialization project which is very different to a simple economic crisis, even if someone insists in its structural characteristics" (Matellanes, 2003, p. 28-29). While the state has been involved in its own de-socialization, the market regulation technologies have conformed societies of control (Deleuze, 2004). Post-industrial societies have become enormously flexible towards differences and peoples' demands, which have been transfigured in consumption capabilities. The system has no long term planning other than the accumulation of profit. However, the number of people excluded from consumerism's privileges has increased dramatically, thus breaking the necessary neo-liberal balance between market subjects and the invisible excluded (Colectivo Situaciones, 2002, p. 37). These consumer capabilities cannot be further guaranteed; neither can the state meet peoples' demands any longer because its possibilities of action, especially in western societies ${ }^{4}$, are tied to those of the global market. The bourgeois hegemony guaranteed by the state and institutions cannot be supported any longer. Consequently, the disarticulation of social bonds leads to the opening of alternatives and possibilities. Societies take charge of their own struggle. This is what John Holloway has called the method of crack:

The method of crack is dialectical, not in the sense of presenting a neat flow of thesis, antithesis and synthesis, but in the sense of a negative dialectics, dialectic of misfitting. (...) The method of the crack is the method of the crisis: we wish to understand capitalism not as domination, but from the perspective of its crisis, its contradictions, its weakness, and we want to understand how we ourselves are those contradictions

(Holloway, 2010, p. 9)

Holloway's last sentence links with Foucault's idea of 'enlightenment', understood as "an ethos, a philosophical life in which the critic of what we are is at one and the same time the historical analysis of the limits that are imposed on us and an experiment with the possibility of going beyond them" (Foucault in Rabinow, 1984, p. 49). In that sense Collectivo Situaciones refers to "new protagonism" as an "ethical action" which, being restricted by the "space of the situation" is responsible for the emancipation from the bio-political networks (Collectivo Situaciones, 2002, p. 38). New protagonism then links mobilization to ethics and knowledge.

Thus, both the reactions to the Argentinian crisis and the $15-\mathrm{M}$ produced a spatial-temporal interruption which cannot be interpreted beyond the limits of its experience and creations of possibilities, although it has opened the door to a transformational existence. The question is how do these events embrace the transformational experience of these encounters? And, how could social movement theories say something about these metamorphoses without falling into the results-led trap? I will attempt to answer these questions by appealing to a shift in peoples' view of participation dynamics. In order to exemplify this shift, I will refer to two platforms in Spain: the PAH (Plataforma de Afectados por la Hipoteca) and the Iaioflautas. I will analyse this shift by looking at the work of activist researchers and a 'minor authors' who, I believe, advocate for the co-production of knowledge between academia and activists. In doing so, these authors de-familiarize the space of social theory in order to understand the nomadic dynamics of current

4 This argument should be contextualized because it is obvious that the state still plays an important coercive role in society. 
social movements.

\section{Re-thinking Participation}

On the 15th of May 2011, people across Spain protested against the consequences of the crisis but also the generalized state of corruption, the electoral system, etc. The protest was organized by Democracia Real Ya (Real Democracy Now) but it soon became clear that nobody and everybody were under this name. After the demonstrations, a few people decided to stay in the city's main square and soon they became thousands. Although many of them had some activist experience, most of the participants did so following their own will, not as members of any particular group. In that sense, at least during the first periods of the encampment, there was a general agreement on rejecting any type of hegemonic form (or structure) as also happened in the 19th and 20th December 2001 in Argentina. From the beginning until the end of the encampments a general assembly decided whether to stay and when to go. This assembly took place every day and everybody could participate, everybody could disagree; the point was to keep the discussion going until a consensual agreement was reached ${ }^{5}$.

After a few days an assembly dynamization manual was agreed. People organized themselves in commissions: food, cleaning, infrastructure, communications, technology, security/mediation, library, strategy commissions, etc. All these commissions were at the same time organized in assemblies where decisions were taken by consensus in spite of time limitations. In fact, the different encampments were virtually coordinated in real time.

Towards the end of the encampments the general assembly and the working commissions reorganized themselves in the Barrios (neighbourhoods). The same practices that were developed in the encampment were transferred to the Barrios. This implies that the participatory languages were now visualized not only through the media. The political debate was taking place on peoples' front doorsteps. The Barrios assemblies took place in the streets, squares and community centres, recovering thus public spaces. The claims of the encampments were re-shaped multiple times, acquiring different nuances in the Barrios where they were being put in place in keeping with the specific demands. This is consistent with the idea of thinking globally but acting locally politics. The concepts of participatory democracy, proportional representation and solidarity practices were debated publicly. Indeed, as Foucault mentions in his work, Discipline and Punishment (1977), people do not need intellectuals to represent their actions. This methodology of political participation is also consistent with the one used during the Italian autonomists movements in the 1970s.

Similarly, except for some theoretical differences, this type of autonomous zone in the centre of the cities has many relations with what Hakim Bey (in Day, 2005, p. 163) calls TAZ (Temporary Autonomous Zone). Bey was not the first one to apply the idea of the encampments. A movable and constantly remodelled area was already developed by the Situationist International, which probably was better known under through the work of Constant Nieuwenhuis of New Babylon (Sadler, 1999). The model advocated by Nieuwenhuis consisted in the creation of a ludic society where movement becomes unpredictable and joyful; prompting the society to change the way life is perceived out of the thought-homogenization of the consumer society. Bey, however, refers to TAZ as nomadic, invisible and non-revolutionary driven encampments because according to him revolution already happened, even if it was during a brief period of time (ibid).

The 15-M events have been reinvented (and reinforced) in multiple movements that enabled the collective thinking of desire and composition. Thus the 15-M reterritorialised a multiplicity of

5 If any agreement was reached, the assembly will continue with the discussion the next day. 
subjectivities into a determined space and time, into a situation, just only to be de-territorialized back to the barrios and again into other collectives, ideas and experiences. To give an example, someone who was an anarchist activist in Barri de Sants (one of the neighbourhoods in Barcelona) and belonged to the Ateneu Llibertari Sants (traditional anarchist reunion space present in most of the Catalan Countries) may have taken part in the 15-M. Later on, s/he might have participated in the 15-M assemblies in his/her neighbourhood of Sants or even, in the general assembly where all the collectives get together to harmonize the actions affecting the community. At the same time, it is probable that this individual also participates in any of the other multiple community projects that take place in Can Batllo (nineteenth century industrial complex that was first occupied, and later conceded by the City Council and is now managed by the neighbours), which, despite it has been part of long term struggle, have gained supporters since the 15-M.

There are several points that need to be mentioned at this stage of the analysis. In contrast to utilitarian theories that conceptualize crises as an opportunity for social movements to claim their piece of cake, the 15-M may be seen as an experience, a crack in the wall of the capitalist system (Holloway, 2010), something that remains in people's imagination. The 15-M is fuelled by peoples' desires to construct new spaces and transforming the old ones. Puerta del Sol and Plaza Catalunya as well as other squares in many cities became not only physical spaces but also temporal ones, which have been deterritorialized in the squares, in the barrios, in platforms, in learning spaces at the neighbourhood associations and collectives. The 15-M changed and became something else. It is true that there has been certain disenchantment with the movement but this is more due to the simple fact that the $15-\mathrm{M}$ movement was presented by the media as the representative of citizens' resistance. This forced the core of the movement, which was composed by people whose activism was there before and beyond "the movement", to reject the movement as a representation and to territorialize in other collectives and activisms actions.

Indeed, the 15-M however, has built the structures and has opened the space for nonexperienced activists to pursue their own participation. Some social theorists, such as Carlos Taibo (2011), mentioned the fear that the movement was going to split and disappear between two types of participants: those that participated because of their personal circumstances, motivated by very concrete objectives, and, those whose participation was directed toward structural changes. In a similar vein, some activists manifested their scepticism on the movement's continuation. Castells, for example, mentions a survey conducted by Simple Lógica in June 2011 (Castells, 2012, p. 119), where although $73 \%$ of the interviewees approved of the protest, only $53 \%$ thought it would help to improve the situation.

I argue however, that these views follow a traditional idea of social movement as homogeneous and organized in a top-down manner. The capacity to break and participate in other assemblies or movements or platforms is part of the rhizomatic behaviours of nomadic movements. The free 'wandering' from a social space to another following different needs and affinities instead of strategically prioritizing, is to accept transformation from diversity to multiplicity.

\section{Transmutation of Values: Every Day Protests}

As mentioned before, the 15-M evolved from previous mobilizations . In turn, the $15-\mathrm{M}$ metamorphosed into other forms of struggles. In this section I discuss more specific examples about how these shifts are perceived by people ${ }^{6}$. Indeed, these changes were firstly reflected on individuals participating in the protests during and after the 15-M. Independently of their

6 It is important to note that these are examples of ongoing processes and therefore it is difficult to capture in article all the complexity of their activity. Thus, what I explain here is rather an overview. 
previous mobilization experiences, individuals from different social background and age came together to demonstrations, flash-mobs, occupations of public and private institutions, boycotts, etc. A glance at any newspapers in Spain is sufficient to be confronted with cynical corruption, frauds committed by the banks, capital moves, jobs, poverty, police force's aggressions, suicides and a general system of structural violence. However, in the newspapers there are also mentioned coloured $^{7}$ waves of every day forms of protest: white (health), green (education), black (public officials), orange (social services and their clients), and purple (woman associations). But also miners, fireman, students and their parents, feminist groups, the list is endless. Between January and September 2012 only, more than 2,732 demonstrations took place in Madrid, 97,97\% more than in 2011 (Público on 27th of September 2012).

I analyse two examples of the transformation enabled by the experience of the 15-M, that is the Iaioflautas and the PAH. These specific examples are used for several reasons. First, both platforms are composed by heterogenic subjects coming from different backgrounds that cannot be identified with the typical activist stereotypes. Second, both platforms are characterized by a horizontal structure (i.e., decisions are taken through shared consensus). Third, many of the individuals have no previous activist's experience. Fourth, importantly, their actions go beyond goal-oriented strategies - participation affects the political, the social and the psychological. Lastly, both platforms have gained support during or after the 15-M.

\section{Iaioflautas}

One of the most prolific platforms conformed already during the encampments of 2011 is the Iaioflautas (http://www.iaioflautas.org/). This is a collective of senior citizens that formed in opposition to the derogatory stereotypes that the right-wing media used to refer to the 15-M. These derogatory stereotypes consisted in relating the movement to the negative significant of those young people with anarcho-punk influences, the perroflautas, or the English word "crusty". The collective re-signified the term and used it in a humorous way, with reference to themselves and their age.

The collective started in Barcelona and spread rapidly around the state gathering senior citizens who identified with the encampments. It demonstrated that these protests were not only a young-people fight, but also represented their new-old struggles. I have selected the Iaioflautas for illustrating my point not only because of the value of their actions, an example of how the 15-M events have transformed the perception of people's political participation, but also because of the symbolism contained in their mere presence. On the one hand, the Iaioflautas broke with stereotypes and assumptions that these types of protest were characteristic of young people coming from a specific ideology. This was the position maintained by the majority of the media and even found in the analysis of recent demonstrations made by some social theorists. On the other hand, the Iaioflautas link their struggles with those of the Spanish transition to democracy as proven by the songs they sing during their actions. Although this would be a topic for another article, the fact that, in the case of the Spanish state, old and new protests are linked within people's imagination leaves a question mark behind the transition to democracy. Thus these protests are not only linked to the current conjuncture of crises, but represent also a rejection of the Spanish democratic process.

Regarding their organization, similarly to the $15-\mathrm{M}$ and all the other collectives and assemblies organized after the encampments, there is no visible head and their composition is heterogeneous. In order to organize their performances, the Iaioflautas makes use of old, and

7 Protesters wear colourful t-shirts according to which protest they feel belonging to. 
modern social media, such as twitter, Facebook, production of memes, etc. Moreover, they also organize acts and events that are no different from those organized by other collectives (e.g., occupying buses, banks, shopping-centres, supporting anti-eviction protest, etc.). The members of this group do not have not specific objectives but multiple ones, nor have they any opportunityled strategy. Rather, they are everywhere, and even if only a few, they are gradually constructing their everyday life and changing people's views on the protests.

\section{Plataforma de Afectados por la Hipoteca}

Another of these experiences is the one of PAH (Plataforma de Afectados por la Hipoteca; platform of people affected by mortgage problems). This collective started from several initiatives such as V of Vivienda, which was constituted in 2006. Its aim was to denounce the corruption in urban planning in the Spanish State and how this was going to affect peoples' degree of debts.

PAH (http://afectadosporlahipoteca.com/) emerged in 2009 in Barcelona. However, as recognised by their own constituency, they started to obtain more tangible results after the 15M. The platform, as other grassroots collectives, is organized horizontally in assemblies (weekly meetings) where individuals experiencing problems with their mortgage gather. During these assemblies, people may get support about their situation and decide collectively how they are going to confront their issues. Starting from their personal drama, they decide on how to act, how to live, recovering their own autonomy and thus, introducing not only a personal change but a collective change in people's consciousness.

They aim to provide alternatives and support concerning two main problems. First, they aim to create awareness of the structural causes that push people to alienation as they cannot keep on paying their mortgage. Second, they aim to find ways to fight the concrete situation of abandonment produced by the loss of people homes ${ }^{8}$. There are currently more than 50 local assemblies spread around the Spanish State, which are in turn coordinated with other assemblies and neighbourhood associations. In order to face this situation, the collective has organized several campaigns. For instance, Stop Deshaucios (evictions) is the most urgent of their initiatives. Affected people, together with family and neighbours, negotiated collectively with the bank and boycotted evictions when the police arrive. Between the 2008 and 2012, 362,776 evictions have been ordered and 577 PAH have continued to mobilize until today. Moreover, several other initiatives organized by the PAH were aimed at finding alternative homes for people, offering structural solutions to the problem, engaging with local institutions and publicly shaming individuals considered responsible for the problem (escraches).

In my view, the two platforms mentioned above correspond to what Collectivo Situaciones has denominated new social protagonism. I have focussed on the afterwards of 15-M because I wished to analyse current protest in Spain beyond "the movement" of 15-M. I wanted to present the different nuances, beyond age, social class and ideology. I have preferred to look at differences among subjectivities and alienations as positive potentiality for the creation of alternatives. I believe, these platforms and initiatives cannot be explained through rationalfunctionalist theories because as the "new protagonism" explained by collectivo situaciones they "seek neither homogeneity nor models, it only raises questions. It exists as a counter-offensive expressed in struggles that are multiple and in forceful dilemmas" (Collectivo Situaciones, 2002, p. 27). These initiatives favour the construction of another discourse of what it is necessary, of what is different and opens possibilities that re-take spaces and construct another type of

8 In Spain the law obliges people to keep on paying their mortgages to the bank even if they have been evicted and returned the keys. 
common sense. Following up on the idea of becoming minor, or as Deleuze says, one has to become woman, not in the sexual sense but as a way of detaching ourselves of the majority and metamorphose in positive difference and thus, transmute. There are thousands of groups and initiatives which any theory could contain if it understands society via its minorities and affinities and through its processes of disembodiment. And in that sense, social theory is "to tie ethics of knowledge to the concrete forms of existence" (ibid, p. 25)

\section{Conclusions}

In this article I have tried to open a debate about the role of social theorists within society. In doing so, I have tried to highlight how social theory has approached the study of social phenomena. Moreover, I have also tried to emphasize how the system's failure left the door open for people's enlightenment and engagement in line with Foucault's discussion. Thus, creating passages that allows lines of flight; from diversity to multiplicity, from becoming majority to becoming woman, becoming child, becoming molecular, transforming the social body from the inside to the exterior.

"The fundamental power struggle", writes Castells, "is the battle for the construction of meaning in the minds of the people" (Castells, 2012, p. 5). To this I would add, in response to the question posed during the afore-mentioned presentation, can we measure this transmutation in people's minds? And if we do, are we not obliged to territorialize, to categorize, to homogenize back these changes and thus missing the resistance that goes beyond rational objectification? Society does not plan and categorize, society acts while theory and policy-making forms run behind. In opposition to the need of rationalization, the social theorist has to become closer to what Deleuze calls the smith, a traveller who "experiences an irrational becoming-object, through jarring encounters with the social-political real-with modes of social existence which cannot, must not, signify" (Day, 2005, p. 175).

I am not trying here to deny or underestimate the benefit stemming from rationalist analyses, but to call for a dialogue between these theories, the approaches of militant researchers and activist practices. In other words, I believe that social research would benefit from co-producing knowledge with social actors and 'minor literature'. In this sense, I argue that to take seriously this co-production of knowledge would push social theory to the plane of consistency and thus initiate a process of deterritorialization necessary to understand the nomadic dynamics of current social actions and movements.

I tried to illustrate this by presenting current debates in social theory through problematizing majoritarian approaches to the study of social phenomena. Militant approaches such as those from Holloway and Collectivo Situaciones present crack, relays, and situations of social protests as a possibility for inaugurating and creating new meanings. These new protagonism and rhizomatic movements have the potential of transforming people's thinking. At the same time, this conceptual framework engages with the participation dynamics developed during the 15-M and inspires other collectives. Both platforms explained above construct their own autonomy and networks working from within, hence transforming and re-shaping people's subjectivities. Against the defeatist arguments that some productivity-led perspectives see in these movements, I have argued here that the true outcome is the one that takes place in people's minds (Castells, 2012, p. 142) or in what Foucault calls "the soul" (Foucault in Day, 2007, p. 135). Social (movement) theory should then decide if it wants to accompany these transformations or on the contrary remain alienated within its own discussions. 


\section{References}

Althusser, L., \& Matheron, F. (1997). The spectre of Hegel: Early writings / Louis Althusser. London: Verso.

Álvarez, K., \& Hessel, S. (2011). Nosotros, los indignados: Las voces comprometidos del 15-M (1st ed.). Barcelona: Destino.

Badiou, A. (2000). Deleuze: The clamor of being. Theory out of bounds: Vol. 16. Minneapolis: University of Minnesota Press.

Bhaskar, R. (1989). Reclaiming reality: A critical introduction to contemporary philosophy. London ; New York: Verso.

Bhaskar, R. (1998). The possibility of naturalism: A philosophical critique of the contemporary buman sciences. London; New York: routledge.

Bleiker, R. (2000). Popular dissent, human agency, and global politics. Cambridge studies in international relations: Vol. 70. New York: Cambridge University Press.

Braidotti, R. (2012). Nomadic Theory: The Portable Rosi Braidotti. New York: Columbia University Press.

Buechler S. M., (1995) New Social Movements Theories. The Sociological Quarterly, 36, 441- 464.

Butler, J. (1990). Gender trouble: Feminism and the subversion of identity. Thinking gender. New York: routledge.

Butler, J., \& Scott, J. W. (1992). Feminists theorize the political. New York: routledge.

Castells, M. (2012). Networks of outrage and hope: Social movements in the Internet age. Cambridge, UK, Malden, MA: Polity.

Chesters, G. (2012). Social Movements and the Ethics of Knowledge Production. Social Movement Studies 11(2), 145-160.

Chesters, G., \& Welsh, I. (2011). Social movements: The key concepts. London: Routledge.

Colau, A., \& Alemany, A. (2013) 2007-2012: retrospectiva sobre desahucios y ejecuciones en España, estadísticas oficiales e indicadores. Retrieved from : http:// afectadosporlahipoteca.com/2013/02/18/ desahucios-y-democracia-de-la-estrategia-delmiedo-a-la-guerra-de-cifras-como-politicadisuasoria/

Collier, A. (1994). Critical realism: An introduction to Roy Bhaskar's philosophy. London ; New York: Verso.

Constant \& Pla, M. (2009) La nueva Babilonia. Barcelona: Gustavo Gili.

Day, R. J. F. (2005). Gramsci is dead: Anarchist currents in the newest social movements. London: Pluto Press.

Deleuze, G., \& Guattari, F. (2004). A thousand plateaus:
Capitalism and schirophrenia / Gilles Deleure, Félix Guattari ; translation and foreward by Brian Massumi. London: Continuum.

Deleuze, G., \& Patton, P. (2004). Difference and repetition. London: Continuum.

Deleuze, G., Felix, G., \& Brinkley, R. (1983). What is a Minor Literature? Mississippi Review, 11, 13-33.

Della Porta, D. \& Rucht, D. (2013). Meeting democracy: Power and deliberation in global justice movements. Cambridge, New York: Cambridge University Press.

Fontana, E. (2002). 19 y 20: Apuntes para el nuevo protagonismo social / [autores, Edgardo Fontana ... et al.7. Colectivo Situaciones. Buenos Aires: Ediciones De Mano en Mano.

Foucault, M. (1995). Discipline and punishment: The birth of the prison. 2. Aufl. New York: Vintage Books.

Foucault, M. (2001). The order of things: An archaeology of the buman sciences. London: Routledge.

Foucault, M., Bouchard, D. F., \& Simon, S. (1977). Language, counter-memory, practice: Selected essays and interviews. Ithaca, N.Y.: Cornell University Press.

Fox N. J. (1998). Foucault, Foucauldians and Sociology. The British Journal of Sociology, 49, 415433.

Gamson, W. A. (1992). Talking politics. Cambridge: Cambridge University Press.

Giddens, A. (1984). The constitution of society: Introduction of the theory of structuration. Berkeley: University of California Press.

Gurr, T. R. (1970) Why men rebel. Princeton, N.J: Princeton University Press.

Habermas J. (1985). Theorie des kommunikativen Handels.

Habermas J \& McCarthy T. (1976). Legitimation crisis. London: Heinemann Educational.

Hessel, S., \& Sampedro, J. L. (2011). jIndignaos!: Un alegato contra la indiferencia y a favor de la insurrección pacifica (1st ed.). Barcelona: Destino.

Holloway, J. (2010). Crack capitalism. London: Pluto Press

Inglehart, R. (1971). Silent revolution in Europe ; The silent revolution in Europe: Intergenerational change inpostindustrial societies. Indianapolis, Ind: BobbsMerrill.

Irigaray, L. (2002). To speak is never neutral. London: Continuum.

Klandermans, B. (1984). Social-Psychological Expansions of Resource Mobilization Theory. 
American Sociological Review, 49, 583-600.

Lane, R. J. (2000). Jean Baudrillard. London: Routledge.

Lyotard, J. F. (1997). The postmodern condition: a report on knowledge. Minneapolis: Univ. of Minnesota Press.

Martínez Z., Casado B., \& Ibarra P. (2012) "Movimientos sociales y procesos emancipadores". Cuadernos de Trabajo/ Lan-Koadernoak Hegoa (57).

Matellanes, M. (2003). Del Maltrato Social. : Conceptos son Afectos. Buenos Aires: EC Ediciones Cooperativas.

McCarthy J. D. \& Mayer Z (1977). Resource Mobilization and Social Movements: A Partial Theory. The American Journal of Sociology, 82, 6, 1212-1241.

Melucci, A. (1996). Challenging Codes: Collective Action in the Information Age. Cambridge University Press: Cambridge.

Melucci, A., Keane, J., \& Mier, P. (1989). Nomads of the present: Social movements and individual needs in contemporary society. London: Hutchinson Radius.

Negri A., Petcou C., Petrescu D., \& Querrien A. (2008). What makes a biopolitical space? A discussion with Toni Negri. Eurozine. Retrieved from: http://www.eurozine.com/ articles/2008-01-21-negri-en.html.

Oberschall A. (1973). Social conflict and social movements. Englewood Cliffs. N.J: Prentice-Hall.

Offe, C. \& Keane, J. (1985). Disorganized capitalism: Contemporary transformations of work and politics. Cambridge: Polity.

Olson, M. (1965). The Logic of Collective Action. Cambridge, MA: Harvard University Press

Opp, K.-D. (2009). Theories of political protest and social movements: A multidisciplinary introduction, critique, and synthesis. London: Routledge.

Parsons, T. (1961). Theories of society: Foundations of modern sociological theory. New York: Free Press of Glencoe.

Rabinow, P. (1984). The Foucault Reader: An introduction to Foucault's thought. London: Penguin Books.

Roffe, J. (2012). Badiou's Deleure. Durham: Acumen Pub.

Rorty, R., Festenstein, M. \& Thompson, S. (2001). Critical dialogues. Cambridge: Polity.

Ross, Kristin (2002). May '68 and its afterlives. Chicago: University of Chicago Press.

Sadler, S. (1998). The situationist city. Cambridge Mass: MIT Press.

Saiedi, N. (1987). A Critique of Habermas' Theory of Practical rationality. Studies in Soriet Thought, 33,
251-265.

Sayer, R. A. (2010). Method in social science: A realist approach. London: Routledge.

Scholl, C. (2012). Two sides of a barricade: (dis)order and summit protest in Europe. Albany: State University of New York Press.

Seidman, S. \& Alexander, J. C. (2001). The new social theory reader: Contemporary debates. London: Routledge.

Seidman, S. (1997). The postmodern turn: New perspectives on social theory. Cambridge: Cambridge University Press.

Smelser, N. J. (1963). Theory of collective behaviour. New York: Free Press of Glencoe.

Smith D. W. (2003). Mathematics and the Theory of Multiplicities: Badiou and Deleuze Revisited. Southern Journal of Philosophy, 41, 441-449.

Shukaitis, S., Graeber, D. \& Biddle, E. (2007). Constituent imagination: Militant investigations// collective theorization. Oakland, CA: AK Press.

Stones, R. (1996). Sociological reasoning: Towards a pastmodern sociology. New York: St. Martin's Press.

Taibo, C. (2011). Nada será como antes: Sobre el Movimiento 15-M. Madrid: Los Libros de la Catarata

Tarrow, S. G. (1998). Power in movement: Social movements and contentious politics. Cambridge: Cambridge University Press.

Tilly, C. (1978). From mobilization to revolution, London: Addison-Wesley.

Urry, J. (2003). Global complexity. Cambridge: Polity Press.

Vaneigem, R. (1983). The revolution of everyday life. Seattle: Left Bank.

Zibechi, R. (2010). Dispersing power: Social movements as anti-state forces. Oakland CA: AK Press. 